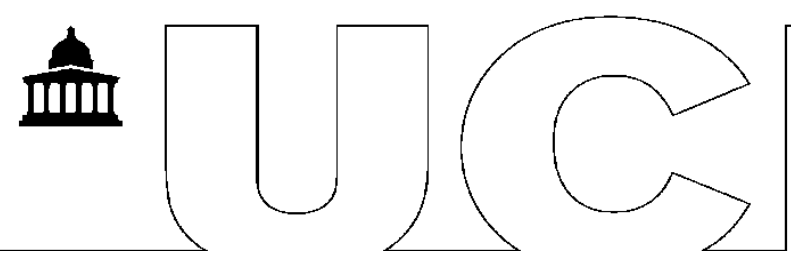

\title{
UCL SSEES
}

Centre for Comparative Economics

\section{Why Do We Need Theory and Metrics of Technology Upgrading?}

\author{
Slavo Radosevic ${ }^{a}$ and Esin Yoruk ${ }^{a}$
}

aSSEES, UCL

Economics and Business Working Paper No.134

February 2015

Centre for Comparative Economics UCLSchool of Slavonic and East European Studies

Gower Street, London, WC1E 6BT

Tel: $+44(0) 2076798519$

Fax: +44 (0)20 76798777 


\begin{abstract}
This paper discusses why we need theory and metrics of technology upgrading. It critically reviews the existing approaches to technology upgrading and motivates build-up of theoretically relevant but empirically grounded middle level conceptual and statistical framework which could illuminate a type of challenges relevant for economies at different income levels. It conceptualizes technology upgrading as three dimensional processes composed of intensity and different types of technology upgrading through various types of innovation and technology activities; broadening of technology upgrading through different forms of technology and knowledge diversification, and interaction with global economy through knowledge import, adoption and exchange. We consider this to be necessary first step towards theory and metrics of technology upgrading and generation of more relevant composite indicator of technology upgrading.
\end{abstract}




\section{INTRODUCTION}

Why do we need theory of technology upgrading? There are three major factors that motivate this paper. First, search for universal factors of growth is futile (see Easterly, 2001). Theories of aggregate economic growth are concerned most often by single variable or factors that can explain economic growth. Seeking for universal theory or single set of factors that can explain growth at different levels of development and in different geographical areas is faced with huge empirical and methodological challenges. Equally, technology is one of the major drivers of growth in long-term is no reducible to single variable be it R\&D or total factor productivity (TFP) (Lee, 2012). The improvements in technological capability arise from increased investments across a number of the drivers of technology upgrading (Furman and Hayes, 2004). The challenge is to figure out which drivers (if any), are common and which are country-specific. Also, drivers differ over the course of development and thus may be quite different for low income, middle and highincome economies. Second, current metrices of technological upgrading are either atheoretical or not rooted in stylized facts of technology upgrading and thus not relevant to low/middle income economies ${ }^{1}$. For example, Global Innovation Index and the EU Innovation Union Scoreboard (IUS) are pragmatic but atheoretical analytical frameworks. By this we mean that they do not have underlying understand of how technology upgrading takes places across different income levels. Currently popular Crépon, Duguet and Mairesse or CDM model (1998) brings together into a simple framework relationship between R\&D, innovation and productivity and thus gives impression that it is theoretically grounded. However, we consider it of limited relevance for countries that operate behind technology frontier as it is based on R\&D as inputs into innovation process which makes it of limited relevance for low and middle income economies. World Economic Forum Global Competiveness Report recognizes differences in drivers of growth which makes it theoretically and empirically grounded but its approach is mixing technological and institutional variables which we consider quite problematic (see below). Third, theoretically grounded but not measurable framework is of quite limited value. Equally metrics that is not grounded in stylized facts or theory is of limited value. Moreover, such metrices can lead to irrelevant policies as it focuses users on issues which are not directly relevant to their growth challenges. A paradigmatic example for this issue is the contradiction in the current EU approach between its dominant metrics (cf. IUS) which assumes identical technological paths and drivers of growth and the wish to push countries along divergent 'smart specialization' paths. The EU is pushing countries and regions to embark on process of formulating their smart specialization strategies to avoid so called 'adding up' problem (Spence 2011: 94-96) or situation that too many regions are aiming for similar technologies and markets and thus competing each other out. However, its dominant metrics (IUS) which countries and regions are using as policy targets is actually reinforcing imitative policies towards R\&D based growth. So, in outcome we have situation that metrics determines policy instead of policy determining metrics.

\footnotetext{
${ }^{1}$ Our notion of middle income economies does not strictly correspond to World Bank classification which we consider outdated. A more accurate definition should include into this category not only currently classified middle income economies (from \$1K- $\$ 12 \mathrm{~K} \mathrm{pc}$ ) but also 'lower' high income economies (\$12K - \$30K) as opposed to opposed to 'upper' high income economies (above \$30K per capita).
} 
Based on these three motivating factors we argue that there is need to generate theoretically relevant but empirically grounded middle level conceptual and statistical framework which could illuminate a type of challenges which seem relevant for a large number in World Bank classification of middle income and 'lower' high income countries (from $\$ 1 \mathrm{~K}-\$ 30 \mathrm{~K} \mathrm{pc}$ ) in their path out of potential middle-income trap. In order to avoid measurement without (some) theory or at least grounding of metrics in stylized facts of technology upgrading we think that there is need to construct composite indicator of technology upgrading, which can complement the existing metrices, especially IUS, and which would reflect better different drivers and patterns of technology upgrading in broadly defined middle income economies.

Our aim is not to use technology upgrading as substitute for economic growth but as one of the major determinants of economic growth. We recognise that some countries can grow to high-income levels without much consideration being given to technology capability. For example, resource based economies and entrepot economies can reach high incomes without necessarily being innovators. Also, economies can reach various income levels based on a variety of institutional systems. From perspective of technology upgrading we are concerned primarily with technology accumulation issues. We assume that very different institutional systems can lead to technology upgrading or that institutional forms are secondary to processes of technology accumulation. Similar to functional views on innovation systems we are primarily concerned with technology activities that increase firm, sector and country level capabilities. Institutional context is quite important variable which in the end is necessary to explain country different performances in growth but our primary concern is with technology upgrading as an issue of accumulation of technology capabilities at different levels.

In the rest of this paper we discuss the issue of technology upgrading in the context of broader literature on technology upgrading. Then we explain our conceptual framework and its assumptions which we propose as a way forward in theorizing and measuring technology upgrading. Conclusions summarize the major points.

\section{PAST AND CURRENT CONTRIBUTIONS TO RESEARCH ON TECHNOLOGY UPGRADING}

\subsection{Past and recent contributions}

Thinking about growth from upgrading perspective is not of recent origin. Marshall in the Principles of Economics (1890) recognised big differences in the dynamics among different economic sectors that have important aggregate effects on growth of economy.

Schumpeter's theory of "Business Cycles" is firmly rooted in analysis of the emergence and decline of leading industries that in aggregate lead to macroeconomic cycles. Simon Kuznets in "Secular, Movements in Prices and Production" (1930) recognised that shifts in the relative importance of leading industries follow life cycles pattern in terms of sales and innovations. Chenery and Syrquin (1975) in "Patterns of development 1950-70" analysed the structural characteristics of the economy by grouping industries in early, middle and late 
ones. The idea of development as evolving process that goes through several stages was first formulated by Rostow (1960) in his stages of growth model. This thinking is based on the idea of industry life cycle and 'leading sectors', which drive growth of economies in specific stages. A common feature of these modes is assumption that "all nations going through the same stages in the same order, though not necessarily at the same times" (von Tunzelmann 1995:69). A similar logic of structural change but in international context has been conceptualized based on Japanese experience as 'Flying-geese model' by Akamatsu (1962). This model depicts changing patterns of industry specialization based on import domestic production - export sequencing which induces structural change in both leader and follower countries. Countries also exhibit similarities in terms of a sequence of structural changes in industrial development not only in the order of 'capital goods following consumer goods' but also 'in the progression from crude to simple goods to complex and refined goods'. This is accompanied by a sequential positioning of the developing countries that are lined up behind the advanced nations so that the former can emulate, learn from and capitalise on growth stimuli/externalities via economic interactions. A latest example of this type of thinking about growth is a structural stages model of growth of Ozawa (2009) which represents a synthesis of stage theories of growth (i.e. Rostow and Akamatsu) and Schumpeter. This model is based on the actual historical path of industrial (hence technological) development (i.e. the ladder of economic development) which is driven by innovations. The outcome is synthesized into a sequential growth in five stages with a leading-sector in each stage. Ozawa's stylization of Japan's industry upgrading is along the following sequence: Labour-driven industries $\rightarrow$ scale-driven $\rightarrow$ assembly-driven $\rightarrow$ R\&D-driven $\rightarrow$ IT-driven. This and previous contributions are largely based in history and thus chart map of upgrading which is based on the historical experience of the leading economies. This is their strength but also weakness as catching up country may not necessarily follow the pattern of leaders as shown by Lee (2013).

The alignment of countries in the process of industrial upgrading has been widely recognised as "countries gradually move up in technological development by following the pattern of countries just ahead of them in the development process" (Radelet and Sachs 1997: 52). This line of thinking has been rejuvenated in the form of new structural economics of Justin Yifu Lin. The idea is that economic development is 'a process of continuous industrial and technological upgrading in which any country, regardless of its level of development, can succeed if it develops industries that are consistent with its comparative advantage, determined by its endowment structure. The successful strategy for developing countries is to exploit the late-comer advantage by building up industries that are growing dynamically in more advanced countries that have endowment structures similar to theirs'. (Lin, 2011:4). So, implicit in ideas of new structural economics is the process of technology upgrading which should be based on country's 'latent comparative advantages'. The econometric evidence for this proposition is quite persuasive and has been tested also in the context of transition economies (Bruno et al, forthcoming). However, this approach seems largely applicable in transformation from low to middle income levels but seemingly less in transition from middle-income to high income. A very important contribution by Lee (2013) is quite persuasive account of transformation from middle income to high-income status and it clearly shows the role of structural change, especially technological diversification as one of the major factors of catching up. While new structural economics accounts (Lin 2012a, 2012b, 2012c) show paths of technology upgrading by 'copying 
industries' based on latent comparative advantages in transition from low to middle income levels Lee (2013) shows middle income economies taking 'detour' or their own path in transition from middle to high income. A very recent contribution to our thinking about technology upgrading in the context of technology specialization and growth is Foray (2015) contribution to conceptually frame and theorize issues based on smart specialization strategies of the EU.

The major recent push to our understanding of technology upgrading came from exploring upgrading which takes place through global value chains. Within this literature industrial upgrading is defined as substantial changes in a country's specialisation and knowledge base that increase its capacity for value generation (Ernst 1998). Gereffi (1999: 51-2) defines it as "a process of improving the ability of a firm or an economy to move to more profitable and/or technologically sophisticated capital and skill-intensive economic niches". Upgrading is usually defined as a process of gradual shift from lower to higher value-added activities; e.g., from cheap and simple products to complex and expensive ones; from mass production of standardised products to flexible production of differentiated products; and, from simple assembly to more integrated forms of production (such as OEM, ODM and OBM). A hierarchy is common feature of taxonomies of upgrading (as seen in the Table 1, particularly in Gereffi and Ernst). Some of taxonomies are theory driven (Gereffi 1998 and Ernst 2001) and some are the outcome of empirical work conducted at the firm level (firm based case studies) (Hobday 1995, Humphrey and Schmitz 2004).

Table 1: Taxonomies of firm level upgrading in international (GVC) context

\begin{tabular}{|l|l|l|}
\hline Authors & Taxonomy / Trajectory & Locus of upgrading \\
\hline Hobday (1995) & $\begin{array}{l}\text { Original Equipment } \\
\text { Manufacturing (OEM) } \\
\text { Original Design Manufacturing } \\
\text { (ODM) } \\
\text { Original Brand Manufacturing } \\
\text { (OBM) }\end{array}$ & International production networks \\
\hline Gereffi (1998) & $\begin{array}{l}\text { within } \\
\text {-factories, } \\
\text {-inter-firm networks, } \\
\text {-local or national economies, } \\
\text { and } \\
\text {-supranational macro-regions }\end{array}$ & Global value chains \\
\hline
\end{tabular}




\begin{tabular}{|l|l|l|}
\hline Ernst (2001) & $\begin{array}{l}\text { hierarchy of } \\
\text {-industries, } \\
\text {-factors of production, } \\
\text {-consumption, } \\
\text {-value chain stages } \\
\text {-forward and backward } \\
\text { linkages }\end{array}$ & $\begin{array}{l}\text { Global production networks (2001, } \\
\text { 2006), } \\
\text { Global knowledge networks (2008), } \\
\text { Global innovation networks (2009) }\end{array}$ \\
\hline $\begin{array}{l}\text { Humphrey and } \\
\text { Schmitz (2004) }\end{array}$ & $\begin{array}{l}\text { Process upgrading } \\
\text { Product upgrading } \\
\text { Functional upgrading } \\
\text { Inter-sectoral upgrading }\end{array}$ & Global value chains \\
\hline
\end{tabular}

It is not surprising that today technology upgrading is most often discussed in international context. Ernst (1997) and Gereffi (1999) are pioneers that initiated the analysis of upgrading via global production networks (GPNs) and the global value chains (GVC) framework. However, as shown by Yoruk (2013) upgrading today is unjustifiably narrowed down to upgrading within value chains or GPN. In a first in-depth study of technology upgrading through value chains in the Central and Eastern Europe context, she shows the major importance of not only production networks but also knowledge networks. In fact, her research shows that learning by doing and learning by exporting do not have statistically significant effect on functional upgrading. She shows that opportunities offered by GVCs will be of little use unless firms have ability to internalise this external knowledge through its human resources, through training and research within the firm. She also shows that managerial upgrading is important to technology upgrading but global buyers do not support it. This highlights the importance of organisational capabilities and suggests that the firms' structure is important structural dimension of technology upgrading.

What are relevant insights from these contributions for understanding theory and metrics of technology upgrading? First, past contributions are largely qualitative insights, which have not been converted into models or stylizations of technology upgrading of countries. Also, contributions by Rostow and Chenery have not been followed by attempts to extend them and apply in a new context. Yet, past contributions share common assumption of some kind of similar or identical path of upgrading. In the light of recent contributions, especially Lee (2013) and Foray (2015) this assumption would need to be qualified or significantly relaxed, especially path of transition from middle to high income. So, 'copying industries' may work in transition from low to middle-income (Lin, 2012b) but diversity and variety of upgrading paths are much more present in subsequent stages. Second, technology upgrading is an interactive process between 'leaders' and 'followers' (Akamatsu, 1962). A literature on GVC clearly shows the overwhelming importance of international context of upgrading but also its limits (Yoruk, 2013). Third, variety of contributions on technology upgrading show that upgrading is multi-level process taking place at firm, industry, inter-industry and country levels. In continuation, we expand on this important feature of technology upgrading. 


\subsection{Multi-level perspectives on technology upgrading}

As we show below literature suggests that upgrading is multi-level phenomenon operating at firm, industry and country level (see Table 2 for summary).

Table 2: Different perspectives on technology upgrading

\begin{tabular}{|c|c|}
\hline Types / Levels & Conceptual framework \\
\hline Intra firm level & $\begin{array}{l}\text {-Reverse product life cycle: A combination of the } \\
\text { product life cycle model in advanced firms by } \\
\text { Utterback and Abernathy (1975) and Kim's (1980) } \\
\text { three stage catch-up model of Acquisition - } \\
\text { Assimilation - Implementation } \\
\text { - Importance of minor improvements during } \\
\text { reverse learning trajectory (Hobday 1995, 1998, } \\
2004 \text { ) }\end{array}$ \\
\hline $\begin{array}{l}\text { Intra-industry and inter- } \\
\text { industry level }\end{array}$ & $\begin{array}{l}\text {-Industry life cycle and dominant design (Klepper, } \\
\text { 1993) } \\
\text {-Upgrading towards high value-added industries } \\
\text { (value chain upgrading) }\end{array}$ \\
\hline Country level & $\begin{array}{l}\text { Sequential upgrading of countries based on } \\
\text { 'leading-sector' (Ozawa 2009) } \\
\text { WEF rankings based on differing drivers of growth } \\
\text { IUS innovation capacity of countries based on } \\
\text { composite indicators of innovation activities }\end{array}$ \\
\hline
\end{tabular}

through so called technology capability approach (Bell and Pavitt, 1992, Dahlman, RossLarsen, and Westphal, 1987, Lall, 1992, Dutrenit, 2000). Rich evidence at firm level has shown paths of upgrading of firms in developing countries through a variety of interrelated, sometimes similar and sometimes unique taxonomies. Based on Korean experience Kim (1980) has proposed a three-stage catch-up model of developing countries firms which goes from acquisition of foreign technology, to assimilation and then to implementation of new product lines. Hobday (1995) himself has explored the path of technology accumulation of East Asian electronics firms during the 1960-1990s. He shows that the best approximation of it is the inverse product life cycle. In contrast to R\&D and design led strategies typical for technology leaders and followers east Asian latecomers have begun with minor improvements in manufacturing process and moved than in reverse towards mastering elements of process technology and only much later mastering elements of design capabilities.

As some of these countries have been moving to a group of high-income economies the issue of firm upgrading have been approached as the issue of transition from catching up to post-catch up stages. When moving to post-catch up stage or to a level of high-income 
economies countries are operating at technology frontier by solving problems that have not been solved by others. Unlike catch-up stage where firms enter largely through reverse product life cycle (PLC) pattern in the post-catch up stage shows firms entering in various stages of PLC (Choung et al, 2014). They can enter similar to reverse product life cycle from production to design and R\&D via large firms; immediately after dominant design has been established to innovate among newly established system architecture via networks of new technology based firms or in early stages of new product life cycles via cooperation between public R\&D organisations and firms (ibid). Along similar lines, there is also a "strategic niche" strategy, 'which involves large number of public, private stakeholders through small-scale transition experiments that expand the scope of changes to a wider scale when the experiments succeed' (Seong et al, 2014).

A trend in literature has been expansion from firm level upgrading to 'industry - level linkages' or industry level upgrading. The underlying rationale for this is the realization that countries' advancement of their firm-level upgrading is increasingly dependent on "industry linkages" (Ernst, 2008). More broadly Ernst (2008) talks about three forms of "industrial upgrading": (i) inter-industry upgrading from low value-added industries (e.g. light industries) to higher value-added industries (e.g. heavy and higher-tech industries); (ii) interfactor upgrading from endowed assets (i.e. natural resources and unskilled labour) to created assets (physical capital, skilled labour, social capital); and (iii) upgrading of demand within a hierarchy of consumption, from necessities to conveniences to luxury goods.

How industries evolve and upgrade is much less understood. The most developed stylization of the dynamics of industry is the industry life cycle, which is either inseparable or quite reliant on already mentioned product life cycle (Abernathy and Utterback, 1978). This view identifies identical three stages as in the evolution of product (Gort and Klepper 1982; Klepper and Graddy, 1990; Utterback and Suarez, 1992; Klepper, 1997). A radical innovation leads to product innovations. In this stage, entry barriers are low and R-D and capital requirements limited, new entrants are most often small firms. This is followed by the emergence of dominant design, which induces a stream of process innovations, but which also improves costs performance ratios. Economies of scale are increasing and equipment become standardised. This increases barriers to entry and lead to industry shakeouts. Finally, as technology matures a few incremental innovations are introduced, industry further concentrates while barriers to entry further increase. Malerba and Orsenigo (1994) succinctly summarize weakness of these stylizations. First, industries are reduced to products, which is far too reductive. Second, the sequence of product innovations followed by process innovations does not hold in capital intensive industries such as commodity chemicals, synthetic fibers, plastics, petrochemicals where innovations are mainly of the process type. Third, in some industries the emergence of a dominant design can actually lead to the new discontinuity or to several dominant designs. Fourth, the radical product innovation that set in motion industry life cycle may be accompanied by very much different industry dynamics in terms of entrants, concentration and incumbents. Entrants may be the existing firms active in related industries while links among firms may continuously change and new type of actors emerging so that boundaries of industry are being continuously redefined. In a nutshell, there seems to be little that we can derive for our issue in terms of useful stylizations or regularities that can be used for our metrics of technology upgrading. Upgrading process does not seem to be correlated to either firm size, or type of innovation. 
A critique of industry life cycle models shows that industry boundaries are ill-defined and changing and need to include a variety of other non-business actors. This highlights the need for inclusion of infrastructure and infrastructural factor as an important factor in evolution and upgrading of industries and economies (see Ozawa, 2010)(see below).

With the rise of composite indicators there has been proliferation of different attempts to measure progress at country level in terms of innovation and competiveness (see Archibugi et al, 2009 for discussion and overview). In a long-term historical perspective Ozawa (2009) depicts sequential upgrading of countries based on leading sectors. WEF GCR rankings depicts ranking of countries based on different drivers of economic growth classifying countries into factor, efficiency and innovation based. EU innovation Scoreboard depicts rankings based on composite indicator of innovation activities ranging from moderate to followers and innovation leaders. Among this group of models of upgrading it is necessary to mention indicator of economic complexity as a dimension by which it is possible to measure upgrading of different countries based on the complexity of their export products. See Hausman et al (2006, 2007a, 2007b, 2009).

As highlighted in this section technology upgrading is a multi-level process and the ultimate pattern of upgrading at country level is a complex interaction between different levels micro, mezzo and macro. This perspective is the most widespread in the context of growth in East Asia and integration of its firms in global production networks. Aggregate explanations of growth have not been able to give satisfactory answers in how these economies managed to achieve upper middle-income status in such short period. Hence, industrial upgrading perspective has shown to be useful in shedding light on micro and mezzo level processes of technology accumulation and to give much richer accounts of drivers of growth than it was possible through variables like total factor productivity or institutions.

In successful cases of catching up or forging ahead we observe high complementarity between different levels and various sub-systems which generate increasing returns (Freeman, 2002, Freeman and Louca, 2001). However, a favourable congruence between various sub-systems of society which have been favourable to economic growth in one period of technological development may not be so favourable when there are fundamental changes in technology (ibid). In short, history shows that technology upgrading is also institutional process and that these institutional requirements are also changing over time. However, for analytical conveniences we need to abstract from institutional set-ups and focus only on outcomes of the learning processes as detected through technology upgrading activities. Complexities of multi-level analysis at which technology accumulation takes place, diversity of its patterns as depicted through structural change as well as interactive nature of technology upgrading are sufficiently complex to justify our abstraction. Our fundamental assumption is firmly rooted in Schumpeterian theorizing both of formal type (Aghion, Akcigit and Howit, 2013) as well as of evolutionary and structuralist direction (Freeman and Louca, 2001, Perez). It is assumption about the relationship between modes of technology upgrading and countries' position in terms of level of development or distance of country from technology frontier. We depict this in figure 1 which suggests that technology upgrading paths are different as economies moves from low to high incomes. When 
countries are far from technology distance they can grow based on imitative technology effort similar to logic explored by Lin (2012). As they move from middle to high income imitative technology efforts do not suffice for catching up so countries need to find alternative paths through technology diversification, not imitation of technology leaders (Lee, 2013). Once they reach post-catch stage they need to embark in activities on technology frontier.

Figure 1: Different patterns of technology upgrading at different income levels

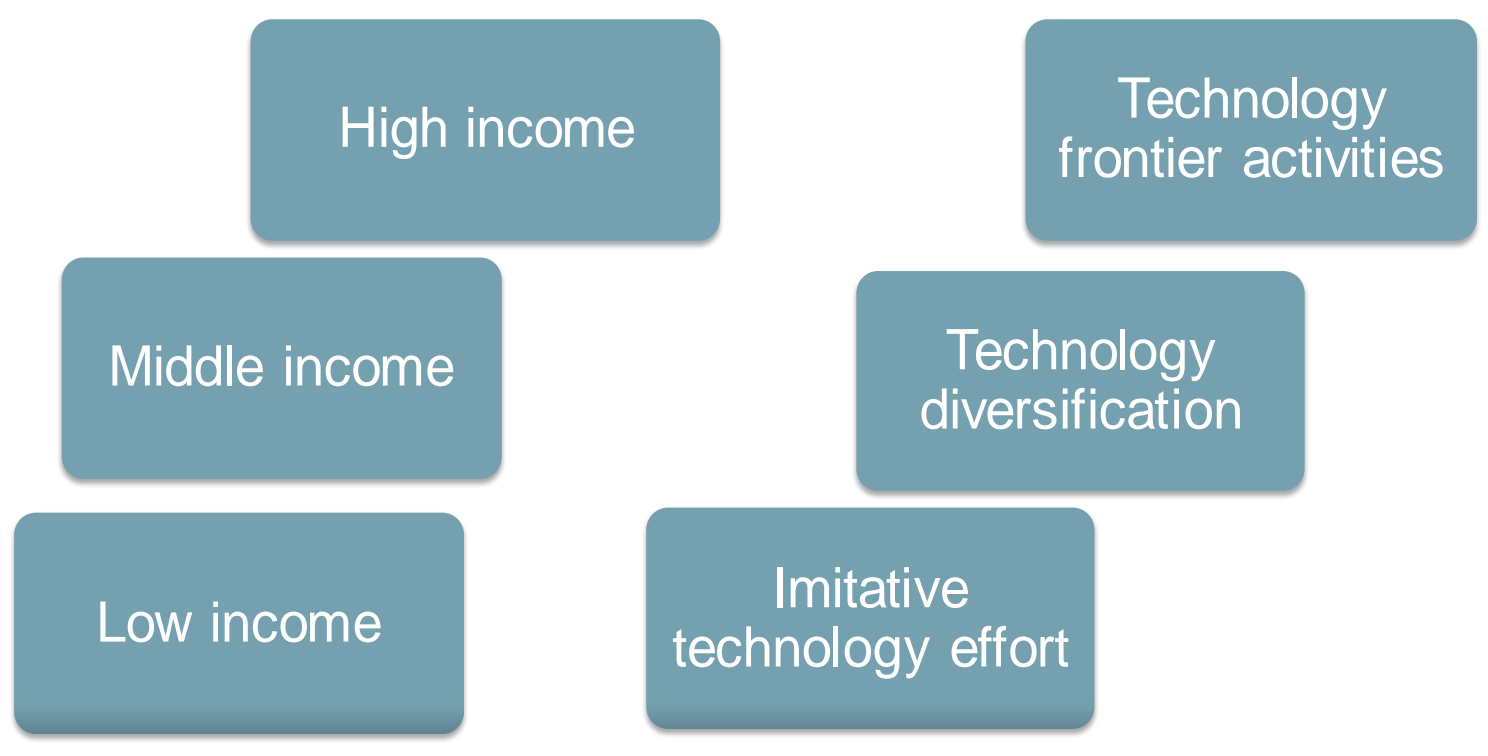

From this follows that technology upgrading targets in countries that operate behind technology frontier should not necessarily draw from those that are suitable for highincome countries. Structural differences including differences in levels of technology upgrading between countries should be taken into account when considering appropriate policies (see Radosevic and Kaderabkova, ed, 2011 for application of this thinking in the context of Eastern Europe).

\section{TECHNOLOGY UPGRADING: CONCEPTUAL ISSUES}

In this section we outline key criteria which need to be met to develop theory technology upgrading. We then outline conceptual approach which includes three dimensions of technology upgrading and its sub-components which hopefully could be used as the basis for building metrics of technology upgrading.

\subsection{CRITERIA FOR BUILDING THEORY OF TECHNOLOGY UPGRADING}


We argue that theory of technology upgrading which is to be grounded in stylized facts of economic growth would need to meet the following criteria:

1. A key to economic growth is in improved technology capability, which cannot be reduced to a single variable (Lee, 2013). Hence, this theory would need to be based on several drivers of technology capability.

2. Technology upgrading is multidimensional process which consists of three major dimensions: technology, structural change and interaction with global economy.

3. Technology upgrading is based on broader understanding of innovation, which goes well beyond R\&D.

4. As we already discussed technology upgrading is a multi-level process which is micro, mezzo and macro grounded. Technological change is never entirely aggregate or entirely micro-based but primarily process of structural change which takes place at micro, mezzo and macro levels. Lee (2012) takes this fully into account by exploring the issue of catching up at all three levels.

5. At the core of technology upgrading is structural change which is also multi-dimensional process: technological, industrial, organisational

6. Technology upgrading is also an outcome of interaction between global actors (embodied in international trade and investment flows) and local technology accumulation activities (pursued by host country firms and governments) (Ernst and Kim, 2002, Lall, 2003, Berend and Ranki, 1982). The key to catch-up and post-catch-up is leverage of domestic innovation efforts with global industrial or knowledge networks (Dieter 2008). Hence, magnitude of knowledge inflows and their coupling to domestic innovation efforts are key dimensions of technology upgrading (Yoruk 2013).

It is important to bear in mind that usual term used is either 'firm level upgrading' or 'industry level upgrading' while we talk about 'technology upgrading'. Economic sectors are increasingly diverse conglomerates of technologies of different levels of complexities and their boundaries are often arbitrary especially in view of changing nature of industry and services (cf. tertiarisation of industry and industrialization of services). The notion of industry is always context specific and should not be reduced on statistical definition of industry at whichever level of aggregation. However, we also recognise that that there is degree of overlap between industry and technology upgrading as some industries are based on more complex technologies than others. In that respect, technology upgrading is about changes in technology intensity but equally about structural change. In fact, these two are inextricably linked as we argue below.

Based on literature review and at very general level we conceptualise technology upgrading as a three-dimensional process (see figure 2). It consists of dimension 1 (vertical axis) which is about intensity of technology upgrading as depicted by different types of innovation activities, of dimension 2 (horizontal axis) which is about spread or width of technology like diversity of technological knowledge, types of supporting infrastructure and firms' structure 
as the carrier of technology upgrading, and of dimension 3 (diagonal axis) which depict knowledge inflows into economy through a variety of forms like trade, FDI and GVC. All three dimensions have strong grounding in the respective literatures on firm level technology upgrading, on structural change and growth, and on integration in global economy ${ }^{2}$.

Figure 2: Dimensions of technology upgrading

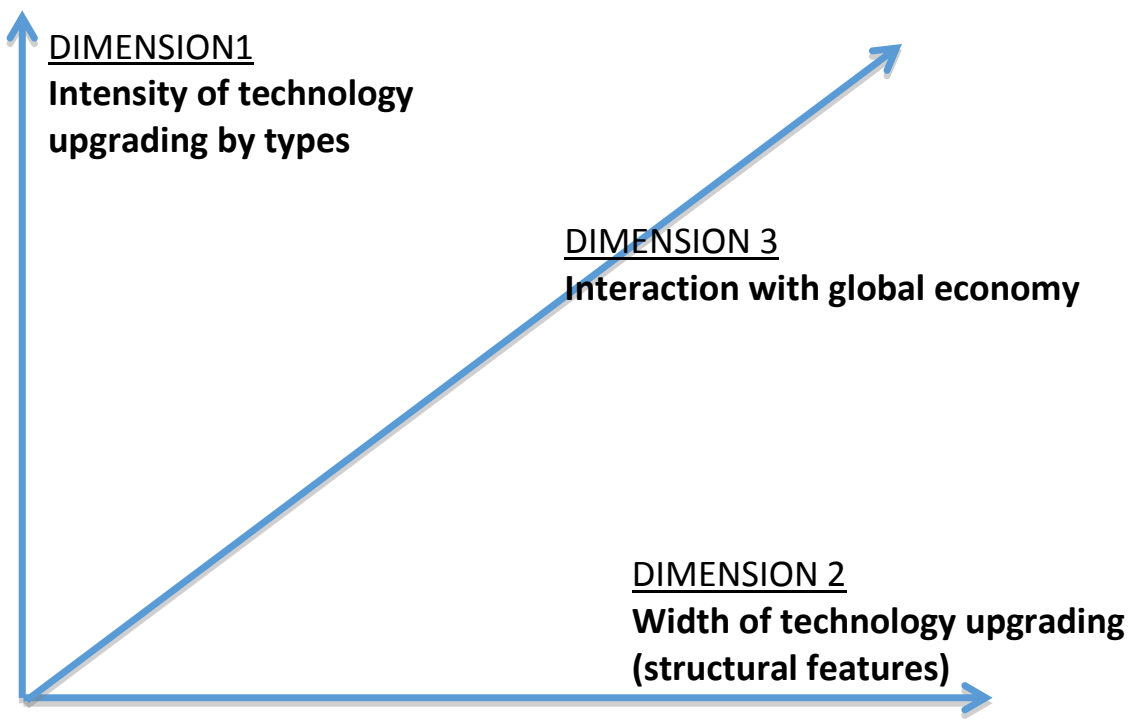

Figure 3: Dimensions and components of technology upgrading
Intensity of
- Production capability
technology
- Technology capability
upgrading by types
- R\&D and knowledge intensity

\section{Interaction with global economy \\ - Technology (embodied) imports \\ - Knowledge imports \\ - Knowledge cooperation}

\section{Breadth of \\ technology \\ upgrading}

- Infrastructure (human, physical, organizational)

- Structural change

- Firms' structure

\footnotetext{
${ }^{2}$ We are fully aware that technology upgrading emerges through interaction between demand and supply factors. However, we consider that bringing demand upgrading into picture would bring another layer of complexity, which would make our conceptual framework unmanageable.
} 


\subsection{INTENSITY AND TYPES OF TECHNOLOGY UPGRADING (SCALE)}

This dimension of upgrading is about acquiring different types of technology capabilities, which are also a reflection of different technological levels of economies. Economies that operate behind technology frontier are more likely to grow based on production capability, not technology capability while high-income economies are more likely to grow based on technology frontier (R\&D based) activities.

By making clear distinction towards industry upgrading and focusing on technology upgrading we can be in danger of focusing only on disembodied knowledge and technology. Given the diversity of forms in which technology is embodied, especially its embodiment in physical inputs and machinery this would be grave mistake. Moreover, innovation activities in latecomer economies are largely about adoption and improvements on imported machinery. Although, technology as stock of knowledge should be kept separate from production, technological capacities and production capacity are in reality strictly interconnected (Bell and Pavitt, 1993). In this respect we differ from Archibugi and Coco (2005) who abstract production from technological capability.

Three types of capabilities, production capability, technology capability, R\&D and knowledge intensity are present in all economies to different degrees. Their importance as drivers of growth varies in dependence of achieved income and technology levels as well as of the structural features of economies. Majcen et al (2009) and Kravtsova and Radosevic (2011) show that for Eastern Europe production capability was significant determinants of growth of productivity, both at micro and at macro levels. This is not unique feature of this region but more general feature of middle income economies as highlighted in figure 4 and by literature on technological capabilities cited earlier. The types of technology capabilities are depicted in figure below which is our reading of seminal piece by Amsden and Tschang (2003) on R\&D indicators.

Figure 4: From production capability to technology capability

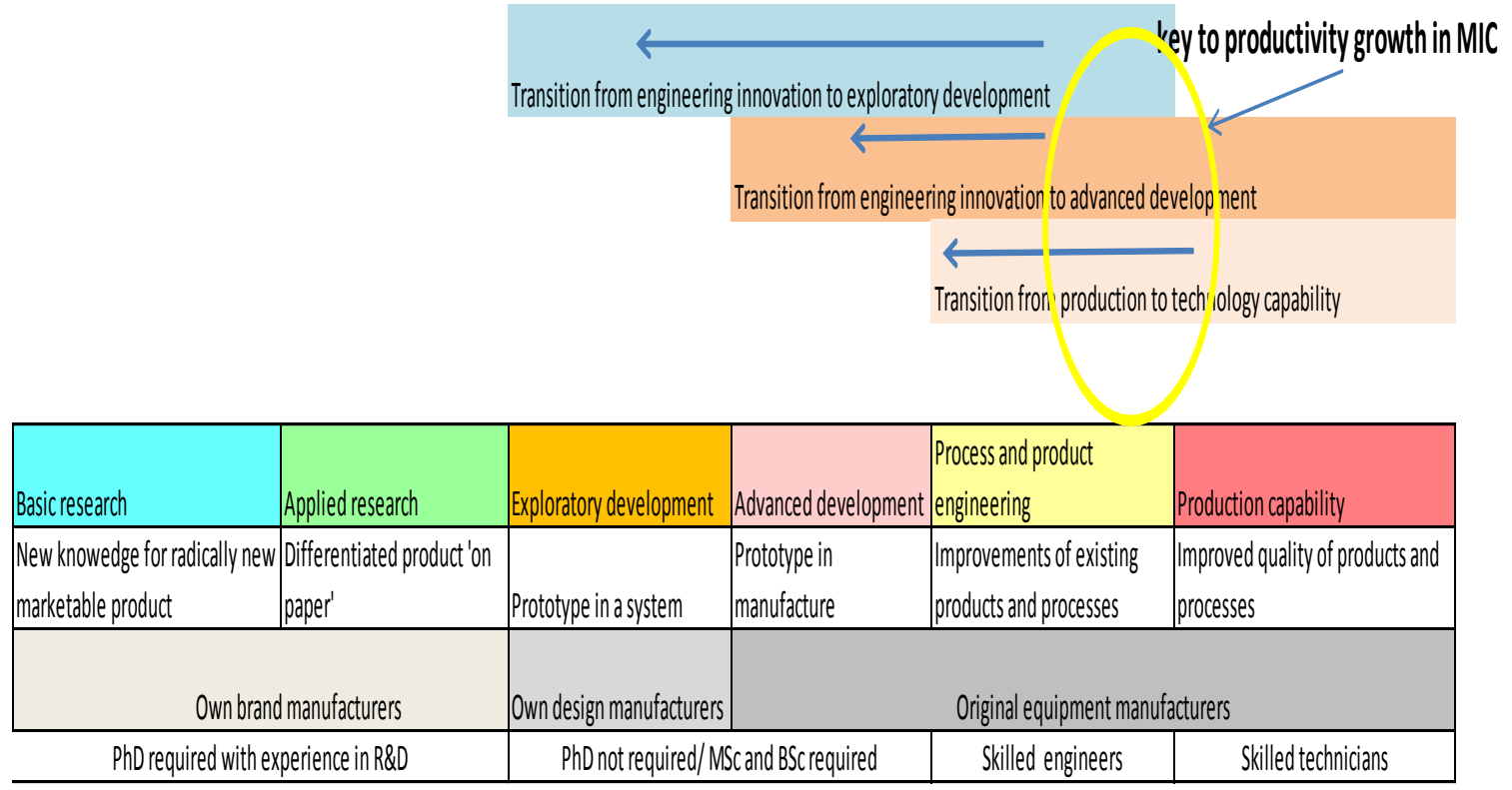

Source: Based on and adapted from Amsden and Tschang (2003) 
Based on figure 4 above we distinguish between production capability, process and product engineering capability, advanced and exploratory development, applied research, and basic research.

Production capability is capability to produce at given level of technology at world levels of efficiency or productivity. This requires primarily good operational efficiency. The key workforce to operational efficiency is skilled technicians or blue-collar workers.

A more complex capability is product and process engineering, which involves improvement in existing products and processes. This capability is largely dependent on skilled engineers. A further stage of this capability is advanced development which Amsden and Tschang (2003) clearly distinguish from exploratory development. Advanced development is about prototype in manufacture while exploratory development is about prototype in a system. There is important threshold level of capability required for firms to move from advanced development, which is development for manufacture to own design manufacture. Production capability, process and product engineering, and advanced development are doable within OEM enterprises while exploratory development is a feature of ODM.

These stages are not necessarily hierarchically structured -i.e. when moving from advanced to exploratory development or from exploratory development to applied research or from applied research to basic research does necessarily involve higher technology complexity (though it may) but simply qualitatively different set of technology or knowledge requirements. Equally, if not more important, upgrading to 'higher' stages is not automatically more rewarding in terms of value added -i.e. upgrading may not necessarily lead to increased incomes but can simply be necessary to maintain the existing levels of income.

Literature on technological capabilities has explored several cases of upgrading from production capability to design capability that can be considered paradigmatic. The best examples of this are cases from East Asia - a region that can be considered paragon of technology upgrading and catch-up. Taiwanese IT industry is a good example of progress from production to design capability in the period over $20-30$ years (Ernst, 2013). Hobday et al (2004) explore the transformation of Korean firms from catch-up to post catch up stage. Also, Dutrenit (2000) provides an in-depth example of transformation from production to OBM world-class capability of the Mexican firm. For Eastern Europe, Radosevic and Yoruk (2004) analyse transformation of ex-socialist electronics conglomerate into contract manufacturer.

These paradigmatic examples show that technology upgrading is not linear and autonomous process but non-linear process with several thresholds levels in this process. A move from one to another stage is not guaranteed and requires a new set of technical, financial and organizational preconditions. Second, past successes are usually new sources of weaknesses, as dual strategies need to be pursued in move from one stage to another. For example, success in technology stage is based on low cost manufacturing capabilities and in capacity to follow technology leaders when introducing manufacturing of new products. A network on which such capability rests are not sufficient for the next stage which requires much more differentiated knowledge networks as well as much larger investment in R\&D based developments and in marketing. Third, a reliance on GVC is the key to success in the 
first stages of production and technology capability. However, these become the major source of vulnerabilities, as technology leadership stage requires much more autonomous development, strong local technology demand and variety of specialized services and knowledge providers.

\subsection{BREADTH OF TECHNOLOGY UPGRADING: STRUCTURAL CHANGE, INFRASTRUCTURE AND FIRMS' STRUCTURE (SCOPE)}

Technology upgrading cannot be reduced on intensity or scale of technological activities. Its additional dimension is breadth or scope of structural factors that affect intensity of technology upgrading. There are three structural factors: structural change itself, infrastructure (human, physical, organizational) and firms' structure.

\subsubsection{Structural change}

There is not general theory of structural change but a variety of theoretical approaches of different methodological nature that aim to explain structural shifts between three broad sectors and among industries within these sectors (Krueger, 2008). There is a common understanding that technological changes affect structural change in the way that industries with relatively lower rates of productivity growth tend to shrink in terms of shares while those with higher rates of productivity growth expand. In this way structural change promote aggregate productivity growth even if we assume that within industries productivity growth remains stagnant. However, the empirical evidence on the role of structural change in aggregate productivity growth escapes broad generalisations and differs very much across different periods and countries or regions. Structural change is often dominated by the within or intra-sectoral effects of productivity growth. Peneder (2003) concludes that structural change generates positive as well as negative contributions to aggregate productivity growth. However, since many of these effects net out, structural change on average appears to have only a weak impact. On the other hand, Sandven et al (2005) show that structural change within manufacturing in OECD countries is not a key feature of the growth process. Growth is primarily based on the internal transformation of low and medium tech sectors rather than on the creation of new sectors. For instance, the incorporation of ICT into medium or low-tech products is only one element of innovation in such sectors.

The issue is complicated by the level at which structural change is observed. Jorgenson and Timmer (2011) show that the division of the economy among agriculture, industry, and services has lost most of its relevance. There is a substantial heterogeneity within the services sector while the use of ICT capital and skilled labour is increasing in all sectors, in particular in the services industries. The linkages among industries and innovations including generic technologies like ICT permeate structural change. The empirical results do not support idea that growth is correlated with the shares of high tech sectors (Sandven et al, 2005). Instead, we observe the changing nature of industries and services and their convergence. This is being captured by knowledge intensive business services (KIBS) which 
are especially important in this development. ${ }^{3}$ Their importance as sources of innovation, technologies and inputs has increased steadily over time. As a consequence, linkages between KIBS and manufacturing industries in different countries have strengthened over time.

Another structural change is the increasing importance of knowledge in all economic activities which is being captured by Knowledge Intensive Activities (KIA) which are defined as economic sectors in which more than $33 \%$ of the employed labour force have completed academic-oriented tertiary education (i.e. at ISCED 5 and 6 levels)(ECR 2011).

Imbis and Wacziarg (2003 have found out that sectoral concentration follows a U-shaped pattern in relation to per capita income. As a result, the increased sectoral specialization applies only to high-income economies. Countries diversify over most of their development path (p.64). This fact is quite in line with robust finding about growth and structural change by Lee (2012) who shows that technology diversification is an important and robust feature of growth from middle to high incomes.

In summary, despite recognising importance of structural change we can derive very little in the way of importance of different sectors and industries in economic growth. The whole point of structural change driven by technology is that it changes boundaries of industries as well as the nature of industries. Hence, using high tech, as proxy of structural change would be highly misleading as high-tech elements permeate many low-tech sectors. Also, catchingup countries are involved increasingly in high tech industries but at low value added segments. So, instead of being focused on structural changes at the level of industries we prefer to focus on more reliable trends regarding technological changes. By this we mean primarily: the increasing importance of ICT in all sectors and activities in economy; the increasing importance of convergence between manufacturing and services as being captured by KIBS; an increasing knowledge intensity of all sectors of economy as captured by KIA indicator; and increasing technology diversification as countries upgrade technologically (see table 2).

Table 3: Components of structural factors of technology upgrading

\footnotetext{
${ }^{3}$ KIBS are defined according to the NACE classification, NACE REV 1.1. as including the categories computer and related activities (NACE 72), research and development (NACE 73) and other business activities (NACE 74).
} 


\begin{tabular}{|l|l|}
\hline $\begin{array}{l}\text { Structural changes } \\
\text { which promote } \\
\text { technology upgrading }\end{array}$ & $\begin{array}{l}\text { ICT as generic technology: proxy of structural } \\
\text { change } \\
\text { Knowledge intensive business services (KIBs) } \\
\text { Knowledge Intensive Activities (KIA) } \\
\text { Technology diversification }\end{array}$ \\
\hline $\begin{array}{l}\text { Infrastructural } \\
\text { upgrading }\end{array}$ & $\begin{array}{l}\text { An important element or externality of technology } \\
\text { upgrading. Inefficiencies in infrastructure can } \\
\text { hinder otherwise competitive firms to upgrade } \\
\text { Infrastructure upgrading (Ozawa, 2009) } \\
\text { Human capital }\end{array}$ \\
\hline Firms' structure & $\begin{array}{l}\text { Share of large firms } \\
\text { Share of SMEs }\end{array}$ \\
\hline
\end{tabular}

\subsubsection{Infrastructural upgrading}

Technology upgrading is primarily taking place in firms but it is not only-firm level business. The accumulation of technology capability in firms must be accompanied by an organizational and institutional infrastructure that supports the acquisition of such capabilities. Choung et al (2014) show that transition from the adoption (catching-up) to the creation stage (post-catch-up) depends on the range of infrastructures that support innovation in a country, in addition to the strategy and resources of a single company. We consider infrastructure to be an important dimension of structural change.

Infrastructure is one component of an economy's endowments, which generates large externalities to other firms' transaction costs. It is both public good and an input in the production of other intermediate inputs. Access to infrastructure services is strongly correlated with a country's average income. Infrastructure matters but the evidence does not provide an unequivocal argument in favour of more or less infrastructure investment (Prud'homme, 2005). Still, despite the obvious problems estimating the direction of causation between infrastructure investment and growth, the evidence suggests that infrastructure causes growth which in turn causes greater demand for (and supply of) infrastructure. As countries reach certain stages of economic development the extent to which infrastructure may represent a binding constraint on development changes. 
Human capital is important driver of growth (Glaeser et al, 2004). A technology embodied in new machinery and equipment will not by itself lead to increased productivity unless there are human skills to effectively use it. A human capital acquired through education is an infrastructural precondition or input into technology upgrading. In addition to school attainments and years of schooling differences in learning achievements matter even more in explaining cross-country differences in productivity growth (Hanushek and Wößmann, 2007). In long run growth is closely related to the level of cognitive skills of the population (Hanushek, 2013). In short, evidence regarding 'quantity' and quality of human capital supports its inclusion as important structural component.

However, in order to be effective human skills need to be part of a specific organisational and economic process that rewards dexterity, learning and innovation. So, human skills unless converted into firm specific skills will not suffice for technology upgrading. Eastern Europe is good example of a region whose labour force post-1989 had relatively high education levels but also low firm specific skills. In post-1989 this has been considered as great advantage and in a few cases led to domestic innovations but with meagre economic results. A good example is Estonian ICT industry (see Hogselius, 2005) which has generated several innovations in IT services. However, a careful examination of this case shows that individual competencies alone are not sufficient without firm specific organisational capabilities. The inherited competencies are strongest at the level of individuals but this is not enough to develop dynamic innovation system without organisational capabilities within which individual competencies can be harnessed. Estonian ICT sector has developed customized innovations, which by definition are not directly transferable to other contexts. These product innovations are easy to imitate or their innovation is in service provision rather than in any unique firm specific accumulated technological competencies. Weak organisational capabilities were further reinforced through marketing barriers to export. Another example is inherited skills in electronics in ten socialist era electronics conglomerates. Only in one case these skills were preserved largely due to organisational capabilities and strategies of top management (see Radosevic and Yoruk, 2004). In all other cases, similar labour force skills were not employed in productive context, which would develop new organisational capabilities within which human capital could be successfully deployed.

Much more known case is of the Indian software whose success is usually attributed to individuals. Indeed, competition by MNEs in labour markets (not competition on product markets) has induced productive efficiency among domestic firms. However, key to use of human capital were organisational capabilities of Indian software firms which were building through imitation and which harnessed to productive use skilled labour force (Athreye, 2005). This leads to the next important structural factor: firms structure.

\subsubsection{Firms' structure}

Schumpeterian economics emphasizes firms' heterogeneity as one of the essential features of industry dynamics (Nelson and Winter, 1985). One aspect of heterogeneity is size differences or the roe of large vs small firms in technology upgrading. The views on the role of large vs. small firms have been quite divided. Chandler (1994) is the most known account of the importance of big business in growth of economy. With advent of 'third industrial 
revolution' and globalization the view emerged that 'the Chandlerian firm is under siege from a panoply of decentralized and market-like forms that often resemble some of the "inferior" nineteenth-century structures the managerial enterprise replaced' (Langlois, 2003).On the hand, there is increasing evidence that globalization has actually reinforced the importance of big businesses. Despite the new institutional framework which gives prominence to markets and networks, global enterprises have remained the major players on global markets. It is true that new paradigm has significantly influenced both the firm boundaries and the patterns of inter-organizational division of labour but the roles of the "visible hand" of organizations and the relative competitive advantages of size such have remained (Dosi et al, 2008). Lee et al. (2013) is so far the most grounded confirmation that there is a significant and robust relationship between the number or sales of big businesses, such as of Fortune 500 firms, and national economic growth even after controlling for country size or endogeneity. They show that among latecomer economies China and Korea, have more big businesses than predicted by country size, whereas other middle-income countries have fewer big businesses than predicted by their sizes, while many high-income countries stay above it. In line with this IFC (2013) survey data show that share of large firms in employment is larger in high income and upper middle income economies when compared to lower income groups. The evidence for the role of SMEs is surprisingly also weaker. Beck et al. (2005) find certain positive but weak correlations between SMEs growth and per capita income without controlling for endogeneity and no significance when endogeneity is controlled.

As organisational capabilities are by definition more complex and more developed in large firms the firms' structure is an important factor of technology upgrading. Based on evidence we formulate working hypothesis that share of large firms is conducive factor of technology upgrading given other things equal.

\subsection{INTERACTION WITH GLOBAL ECONOMY FOR TECHNOLOGY UPGRADING}

A successful technology upgrading is never entirely autonomous process but is always linked to inflow of foreign knowledge skills, which are coupled with intensive domestic technology effort (Radosevic, 1999). A literature that documents that is far too lengthy and only a few examples will suffice to reiterate this robust but often forgotten stylized fact (Mowery and Oxley, 1997, Kim 1997, Amsden 2001). The emphasis is usually on one of these two elements of catching up - either on domestic technology accumulation or on inflows of foreign knowledge through trade, FDI and generally open economic regime.

Literature on FDI and technology upgrading or knowledge spillovers is quite numerous. A meta-review of this literature by Bruno and Campos (2013) shows that the effect of FDI on economic performance and growth are conditional. Firms, sectors or countries that are below certain "thresholds" (either in terms of human capital, financial development or institutional quality) are less likely to benefit from FDI. In overall, benefits are significantly greater in low-income than in lower and upper middle-income countries (both at the micro 
and macro level). Available data provide stronger support for differentiating the effect of FDI on growth across levels of development rather than in terms of geographic regions. The effect at the macro level depend upon whether recipient countries have attained minimum levels of human capital, financial and institutional development. The effects of FDI using firm-level data tend to find that the (micro-) effect is conditional upon the type of linkages (with backward linkages, that is, links between the firm and its suppliers, dominating over horizontal or forward linkages).

Indeed, FDI is a potential source of technology upgrading. Integration into the global economy and foreign direct investment (FDI) can act as important catalysts for change but equally FDI alone are not driver of technology upgrading. As literature suggest their effects on upgrading are highly differentiated and dependent on indigenous technology effort. Even when countries are integrated globally in R\&D networks they do not necessarily link up with domestic manufacturing value chain which lead to what Ernst (2014) describes on the example of Indian electronics as 'truncation of FDI based learning'. He explains this by fragmented Indian national innovation system in which local electronics manufacturing remains disconnected from India's chip-design capabilities which are integrated, instead, into global networks of innovation and production.

FDI indicators are of limited value in detecting the true knowledge that is acquired through international industrial networks. Research on GVC is useful in that respect though it is difficult to generalise. Different contributions show the positive and significant effects of learning through value chains on process, product and functional upgrading up to ODM level. Yoruk (2013) shows the major importance of both knowledge and production networks for firms' upgrading but also that is highly misleading to narrowing learning opportunities for upgrading to interactions with the global buyers within GVCs. Her research in the case of Eastern Europe shows that learning by doing and learning by exporting do not have statistically significant effect on functional upgrading. She shows that opportunities offered by GVCs will be of little use unless firms have ability to internalise this external knowledge through its human resources, through training and research within the firm. She also shows that managerial upgrading is important to technology upgrading but global buyers do not support it. This again highlights the importance of organisational capabilities or firms' structure that we discussed under structural dimension of technology upgrading.

Globalisation of technology exploitation and collaboration but also technology generation through globalization of $R \& D$ process has further increased the importance of international linkages for industrial upgrading (UNCTAD,2005). A very recent example of the importance of integration into global value chains and its growth benefits is German - Central European supply chain cluster (GCESC)(IMF 2013, IMF 2013b). The increase in foreign value added in four major countries locations of GCESC (Czech Republic, Slovakia, Poland and Hungary/CE4) 
appears to have led to increases in domestic value added through productivity increases as well as by creating demand for ancillary products and services in host economies. It seems that participation in the GCESC has led to considerable technology transfers to the CE4 countries though there is not yet clear consensus about its magnitude due to high heterogeneity among firms in terms of fostering skills.

The weakness of many technologies upgrading metrices is that they are focused on explicit domestic technology effort or import of knowledge via licences but neglect knowledge inflows in embodied form via imported inputs and equipment. In countries behind technology frontier growth is mainly driven by diffusion and absorption of technologies that are new to the firm or country but not new to the world. Domestic knowledge generation in business enterprises sector through R\&D or non-R\&D technical activities as well as accumulation of knowledge in public R\&D system is not yet the major driver of growth when compared to indirect knowledge and R\&D embodied in imported inputs and machinery. $R \& D$ activity performed in industries other than the one where own R\&D is being carried out have a significant effect on productivity growth. Own-R\&D activity accounts for about onehalf of the total R\&D content in countries at the technological frontier, and between onequarter and one-half of the total R\&D content in countries below the frontier (Knell, 2008).

Finally, mobility of people is one of the most effective channels of knowledge transfer and of technology upgrading. This is the key mechanism for conveying tacit knowledge as well as initiator of learning.

Out of three dimensions of technology upgrading the interaction with global economy is probably the most difficult to capture since technology transfer happens through capital equipment import, is embedded in modes like FD, networks and subcontracting or is disembodied (licences). However, modes of transfer by themselves cannot be taken as proxies of the real knowledge transfer that has taken place (Radosevic, 1999). In view of that complexity we consider distinction between technologies (embodied) imports, knowledge imports (licences) and knowledge cooperation (RD cooperation) as components of interaction with the global economy dimension which are distinctive but are also possible to capture through data.

\section{CONCLUSIONS}

We argued in this paper that we need theory and metrics of technology upgrading for the following reasons. First, aggregate theories of growth are not useful and represent a kind of 'holy grail' of growth theory. Second, current metrices of technology upgrading are either 
atheoretical or are not useful for countries behind technology frontier. Third, such metrices lead to misleading or irrelevant policies. Hence, there is a need to generate theoretically relevant but empirically grounded middle level conceptual and statistical framework which could illuminate a type of challenges which are relevant for a large number of economies at different levels of income.

We have reviewed literature relevant to this idea and have derived conceptual framework which we consider as useful way to approach to theory and metrics of technology upgrading. In nutshell, we conceptualize technology upgrading as three dimensional processes composed of the following dimensions: Intensity and different types of technology upgrading through various types of innovation and technology activities; a widening (broadening) of technology upgrading through different forms of technology and knowledge diversification, and interaction with the global economy through different forms of knowledge import, adoption and exchange. We discussed each of these dimensions in some detail pointing to their major components and justifying why they are important to our understanding of each of three dimensions of technology upgrading. We consider this to be necessary first step towards theory and metrics of technology upgrading and generation of relevant composite indicator for technology upgrading of countries at different levels of income.

\section{REFERENCES}

1. Abernathy, W.J. and Utterback, J.M. (1978) Patterns of Industrial Innovation. Technology Review.vol.8, iss.7, p.40-47.

2. Acemoglu, Daron, Fabrizio Zilibotti and Philippe Aghion (2006) Journal of the European Economic Association, Vol. 4, No. 1 (Mar., 2006), pp. 37-74

3. Akamatsu K.(1962): A historical pattern of economic growth in developing countries. Journal of Developing Economies, 1(1):3-25, March-August.

4. Archibugi Daniele and Alberto Coco (2005) Measuring technological capabilities at the country level: A survey and a menu for choice, Research Policy 34 (2005) 175-194

5. Archibugi, D., Denni, M. and Filippetti, A. (2009) 'The technological capabilities of nations: A review of the synthetic indicators'. Technological Forecasting and Social Change, Vol. 76, No. 7, pp. 917-31.

6. Amsden Alice H. and F. Ted Tschang (2003) A new approach to assessing the technological complexity of different categories of R\&D (with examples from Singapore), Research Policy 32 (2003) $553-572$

7. Amsden, Alice H. (2001) The Rise Of "The Rest". Challenges to the West from Late-Industrializing Economies, Oxford University Press. 
8. Aghion, Philippe, Ufuk Akcigit and Peter Howitt (2013) What Do We Learn From Schumpeterian Growth Theory? NBER Working Paper Series No 18824, February

9. Athreye, Suma (2005) "The Indian Software industry and its evolving service capability"; Industrial and Corporate Change, Vol. 14(3): 393-418.

10. Beck T. Demirguc_Kunt A, Levine R (2005) SMEs, growth and poverty: Cross-country evidence, Journal of Economic Growth, 10(3):199-229.

11. Bell, M. and K. Pavitt (1993) "Technological Accumulation and Industrial Growth: Contrasts between developed and developing countries", Industrial and Corporate Change, 2(2): 157-210.

12. Bell, Martin and Keith Pavitt (1997) Technological accumulation and industrial growth: contrasts between developed and developing countries, in Daniele Archibugi, Jonathan Michie, (eds), Technology, Globalisation and Economic Performance,

13. Berend Iván T. and György Ránki (1982) The European Periphery and Industrialization, 17801914, New York: Cambridge University Press

14. Bruno Randolph L. and Nauro F. Campos (2013) Reexamining the Conditional Effect of Foreign Direct Investment, IZA Discussion Paper No. 7458, June 2013. Available at http://papers.ssrn.com/sol3/papers.cfm?abstract id $=2287068$

15. Bruno, R., E. Douarin, J. Koosteleva and S. Radosevic (forthcoming) Technology Choices and Growth: Testing New Structural Economics in Transition Economies, Journal of Economic Policy Reform.

16. Chenery Hollis and Moises Syrquin (1975), Patterns of development, 1950-1970, (World Bank) Oxford University Press, Oxford.

17. Chandler, Alfred D. Jr (1994) Scale and Scope. The Dynamics of Industrial Capitalism, Harvard University Press.

18. Choung, Jae-Yong, Hye-Ran Hwang and Wichin Song (2014) Transitions of Innovation Activities in Latecomer Countries: An Exploratory Case Study of South Korea, World Development Vol. 54, pp. 156-167, 2014

19. Crépon, B., E. Duguet and J. Mairesse (1998), "Research and Development, Innovation and Productivity: An Econometric Analysis at the Firm Level", Economics of Innovation and New Technology, 7(2), 115-158.

20. Dahlman, C., Ross-Larsen, B. and Westphal, L.E. (1987), Managing technological development: Lessons from the Newly Industrializing Countries, World Development, Vol.15, No. 6, 759-775.

21. Dosi, Giovanni, Alfonso Gambardella, Marco Grazzi, Luigi Orsenigo (2008) Technological Revolutions and the Evolution of Industrial Structures: Assessing the Impact of New Technologies upon the Size and Boundaries of Firms, Capitalism and Society, Volume 3, Issue 12008 Article 6:1-47

22. Dutrenit, Gabriela (2000) Learning and Knowledge Management in the Firm: from Knowledge Accumulation to Strategic Capabilities, Edward Elgar: Aldershot, England. 
23. Easterly, William (2001) The Elusive Quest for Growth. Economists' Adventures and Misadventures in the Tropics, MIT Press, Cambridge, Mass.

24. Ernst Dieter (2014) Upgrading India's electronics manufacturing industry : regulatory reform and industrial policy, East West Centre, Honolulu,

25. Ernst, Dieter (2008) Asia's "upgrading through innovation" strategies and global innovation networks: an extension of Sanjaya Lall's research agenda, Transnational Corporations, Volume 17, Number 3, December 2008

26. Ernst, D. (1998) "Catching-Up, Crisis and Industrial Upgrading. Evolutionary Aspects of Technological Learning in Korea`s Electronics Industry “, Asia Pacific Journal of Management, Volume 15 (2): 247-283.

27. Ernst, D. (2001) “Global Production networks and Industrial Upgrading - A Knowledge Centred Approach", East-West Center Working Papers, Economics Series, No. 25.

28. Ernst Dieter (2013) Industrial Upgrading through Low-Cost and Fast Innovation - Taiwan's Experience, East-West Center working paper, Honolulu, Economics Series, No. 133, September 2013

29. Ernst, D. and Kim, L. (2002) Global production networks, knowledge diffusion and local capability formation. Research Policy, 31: 1417-29.

30. Ernst, D. (2008) "Can Chinese IT Firms Develop Innovative Capabilities Within Global Knowledge Networks?”, East-West Center Working Papers, Economics Series, 94.

31. Ernst, D. (1997) “From Partial to Systemic Globalization: International Production Networks in the Electronics Industry", BRIE Working Paper 98.

32. European Competitiveness Report 2011, Chapter 2 'Convergence of knowledge intensive sectors and the EU's external competitiveness' (further ECR 2011)

33. Foray, Dominique (2015), Smart specialization. Opportunities and challenges for regional innovation policy, Routledge.

34. Freeman, Chris (2002) Continental, national and sub national innovation systems complementarity and economic growth, Research Policy 31: 191-211.

35. Freeman Chris and Francisco Louçã (2001) As Time Goes By From the Industrial Revolutions to the Information Revolution, Oxford University Press.

36. Furman Jeffrey L. and Richard Hayes (2004) Catching up or standing still? National innovative productivity among 'follower' countries, 1978-1999 Research Policy 33 (2004) 1329-1354

37. Gort Michael and Steve Klepper (1982) Time Paths in the Diffusion of Product Innovations, The Economic Journal, Vol. 92, No. 367 (Sep., 1982), pp. 630-653

38. Glaeser, Edward L., Rafael La Porta, Florencio Lopez-de-Silanes and Andrei Shleifer. "Do Institutions Cause Growth?," Journal of Economic Growth, 2004, v9(3,Sep), 271-303. 
39. Hanushek Eric A. and Ludger Wößmann (2007) Education Quality and Economic Growth, World Bank, Washington.

40. Hanushek, E., Economic Growth in Developing Countries: The Role of Human Capital, Economics of Education Review (2013), http://dx.doi.org/10.1016/j.econedurev.2013.04.005

41. Hobday, M., H. Rush., J. Bessant (2004) Approaching the innovation frontier in Korea: the transition phase to leadership, Research Policy 33:1433-1457.

42. Hogselius, Per The (2005) Dynamics of Innovation in Eastern Europe: Lessons from Estonia, Edward Elgar, Cheltenham

43. Hobday, M. (1995) "East Asian Latecomer Firms: Learning the Technology of Electronics, World Development, 23(7): 1171-1193.

44. Humphrey, J. and Schmitz, H. (2004) 'Governance in global value chains', in H. Schmitz (ed.) Local Enterprises in the Global Economy. Issues of Governance and Upgrading, Edward Elgar: Cheltenham, UK, 95-109.

45. Hausmann, R., J. Hwang, and D. Rodrik. 2007a. "What You Export Matters." Journal of Economic Growth 12:1-25.

46. Hausmann, R. and B. Klinger. 2006. "Structural Transformation and Patterns of Comparative Advantage." CID Working Paper No. 128. Cambridge, MA: Center for International Development, Harvard University.

47. Hidalgo, C., and R. Hausmann. 2009. "The Building Blocks of Economic Complexity." Proceedings of the National Academy of Sciences 106(26): 10570-10575.

48. Hidalgo, C., B. Klinger, A. L. Barabasi, and R. Hausmann. 2007b. "The Product Space Conditions the Development of Nations." Science 317: 482-487.

49. Imbis Jean and Roman Wacziarg, Stages of diversification, American Economic Review 2003. Vol. 93, No. 1, pp. 63-86.

50. IMF (2013) "German-Central European Supply Chain-Cluster Report", IMF Country Report 13/263, August 20th, 2013

51. IMF (2013b) Trade Linkages, Balance Sheets, and Spillovers: The Germany-Central European Supply Chain, Prepared by Selim Elekdag and Dirk Muir, IMF Working Paper, European Department, October 2013

52. Jorgenson Dale W. and Marcel P. Timmer (2011) Structural Change in Advanced Nations: A New Set of Stylised Facts, Scand. J. of Economics 113(1), 1-29, 2011

53. Kim, L. (1980) Stages of development of industrial technology in a less developed country: a model, Research Policy 9(3):254-277

54. Kim, L. (1997) Imitation to Innovation: The Dynamics of Korea's Technological Learning, Boston, Harvard Business School Press. 
55. Knell Mark (2008) Product-Embodied Technological Diffusion and Intersectoral Linkages in Europe, 28 April, Innovation Watch - SYSTEMATIC, NIFUSTEP

56. Kuznets, S. (1930) Secular Movements in Production and Prices: Their nature and their bearing upon cyclical fluctuations. Houghton Mifflin, Boston and New York, repr. Kelley, New York, 1967.

57. Lall, S. (1992), Technological capabilities and industrialization, Research Policy, Vol. 20, No. 2, 165-186

58. Langlois Richard N.(2003) Chandler in a Larger Frame: Markets, Transaction Costs, and Organizational Form in History, Business and Economic History, Vol.1 (On line) http://www.thebhc.org/publications/BEHonline/2003/Langlois.pdf

59. Lee Keun, B Y Km, Y Y Park, E Sanidas (2013) Big business and economic growth: identifying a binding constraint for growth with country panel analysis, Journal of Comparative Economics, 41 (2):561-82

60. Lee, Keun (2013) Schumpeterian analysis of economic catch-up, Knowledge, Path-creation and the middle-income trap, Cambridge University Press. .

61. Lin Justin Yifu (2011) From Flying Geese to Leading Dragons New Opportunities and Strategies for Structural Transformation in Developing Countries, Policy Research Working Paper 5702, World Bank

62. Lin Justin Yifu (2012a) From Flying Geese To Leading Dragons: New Opportunities and Strategies for Structural Transformation in Developing Countries, Global Policy Volume 3 . Issue 4 . November 2012: 397-407

63. Lin, Justin Yifu (2012b) New Structural Economics. A Framework for Rethinking Development and Policy. The World Bank, Washington D.C.

64. Lin Justin Yifu \& David Rosenblatt (2012c): Shifting patterns of economic growth and rethinking development, Journal of Economic Policy Reform, 15:3, 171-194

65. Majcen, Boris, Slavo Radosevic, Matija Rojec (2009) Nature and determinants of productivity growth of foreign subsidiaries in Central and East European countries, Economic Systems, 33 (2009) 168-184

66. Marshall, A. (1890) Principles of Economics. C.W. Guillebaud (ed), 9th edn, vol.1, Macmillan/Royal Economic Society, London, 1961.

67. Mowery, D.C. and J. Oxley (1997) "Inward Technology Transfer and Competitiveness: The Role of National Innovation Systems", in Technology, Globalisation and Economic Performance, D. Archibugi and J. Michie (eds.), Cambridge University Press.

68. Nelson Richard R. and Sidney G. Winter (1985), An Evolutionary Theory of Economic Change, Belknap Press.

69. Klepper, S. and E. Graddy (1990), The Evolution of New Industries and the Determinants of Marke Structure,' Rand Journal of Economics, 21, 27-44 
70. Klepper, Steven (1997) Industry Life Cycles, Industrial and Corporate Change, Vol., 6, No.1: 145181.

71. Kravtsova,V. and Radosevic,S. (2011) Are systems of innovation in Eastern Europe efficient? Economic Systems, doi:10.1016/j.ecosys.2011.04.005

72. Krueger, Jens J. (2008) Productivity and structural change: a review of the literature, Journal of Economic Surveys (2008) Vol. 22, No. 2, pp. 330-363

73. Malerba Franco and Luigi Orsenigo (1994) The Dynamics and Evolution of Industries, Working Paper WP-94-120, November 1994, The International Institute for Applied Systems Analysis

74. Ozawa, Terutomo (2009) The Rise of Asia, The 'Flying Geese' theory of tandem growth and regional agglomeration, Edward Elgar, Cheltenham.

75. Peneder Michael (2003), Industrial structure and aggregate growth, Structural Change and Economic Dynamics, 14 (2003): 427-448

76. Perez Carlota (2010) Technological revolutions and techno-economic paradigms, Cambridge Journal of Economics 34: 185-202

77. Prud'homme, Rémy. 2005. "Infrastructure and Development», in: Bourguignon, François \& Boris Pleskovic, ed. 2005. Lessons of Experience (Proceedings of the 2004 Annual Bank conference on Development Economics). Washington: The World Bank and Oxford University Press, pp. 153-181.

78. Radelet, Steven and Jeffrey Sachs (1997) Asia's Re-emergence, Foreign Affairs, November/December

79. Radosevic, S. (1999) International technology transfer and catch-up in economic development, Edward Elgar, Cheltenham.

80. Radosevic, S. and D. E. Yoruk, 'The growth of enterprise through entrepreneurship and network alignment', In Radosevic, S. and B. Sadowski (Eds.)(2004), International industrial networks and industrial restructuring in central Europe, Russia and Ukraine, Kluwer, 2004, pp.109-130

81. Radosevic Slavo and Anna Kaderabkova (eds) (2011) Challenges for European Innovation Policy: Cohesion and Excellence from a Schumpeterian Perspective, Edward Elgar, Cheltenham

82. Radosevic, S. and Yoruk, D.E. 2004, "The Growth of Enterprise Through Entrepreneurship and Network Alignment" in S. Radosevic and B.M. Sadowski (eds), International Industrial Networks and Industrial Restructuring in Central and Eastern Europe, Kluwer, Dordrecht, the Netherlands.

83. Rostow, W.W. (1960) The stages of economic growth: A non-communist manifest. Cambridge University Press, Cambridge; 2nd enlarged edn, 1971.

84. Seong, Jieun, Jongseon Kim and Yejin Cho (2014) Korea's Post Catch-up Policy Experiment: Focusing on the Transition towards a Sustainable Socio-technical System, Paper prepared for thematic issue of AJTM 
85. Sandven, Tore, Keith Smith and Aris Kaloudis (2005), Structural change, growth and innovation: the roles of medium and low tech industries, 1980-2000, In H. Kreinsen et al (eds), Low-tech Innovation in the Knowledge Economy, Frankfurt: P. Lane. Jan 292005

86. Suarez Fernando and James Utterback (1995) Dominant designs and the survival of firms, Strategic Management Journal, Vol. 16, 415-430.

87. Yoruk, D.E. (2013) Firm-level upgrading in low- and medium-technology industries in emerging markets: the role of learning networks, PhD thesis, University of Sussex, December, SPRU.

88. UNCTAD (2005) World Investment Report, UN, Geneva

89. Von Tunzelmann, G.N. (1995) Technology and Industrial Progress: The Foundations of Economic Growth, Edward Elgar, Aldershot 